\title{
MANUSIA DAN KEBUDAYAAN \\ (MANUSIA DAN SEJARAH KEBUDAYAAN, MANUSIA DALAM \\ KEANEKARAGAMAN BUDAYA DAN PERADABAN, MANUSIA DAN SUMBER PENGHIDUPAN)
}

\author{
Mahdayeni $^{1}$ Muhammad Roihan Alhaddad ${ }^{2}$ Ahmad Syukri Saleh ${ }^{3}$ \\ ${ }^{1}$ IAI Nusantara Batanghari Jambi \\ ${ }^{2}$ STIT Raudhatul Ulum Sakatiga \\ ${ }^{3}$ Universitas Islam Negeri Jambi \\ email: langelina99@gmail.com
}

\begin{abstract}
Abstrak
Keragaman dalam masyarakat majemuk merupakan sesuatu yang alami yang harus dipandang sebagai suatu fitrah. Hal tersebut dapat dianalogikan seperti halnya jari tangan manusia yang terdiri atas lima jari yang berbeda, akan tetapi kesemuanya memiliki fungsi dan maksud tersendiri, sehingga jika semuanya disatukan akan mampu mengerjakan tugas seberat apapun. Untuk menyadari hal tersebut, Bhinneka Tunggal Ika memiliki peran yang sangat penting. Pengembangan multikulturalisme mutlak harus dibentuk dan ditanamkan dalam suatu kehidupan masyarakat yang majemuk. Jika hal tersebut tidak ditanamkan dalam suatu masyarakat yang majemuk, agar kemajemukan tidak membawa pada perpecahan dan konflik. Indonesia sebagai bangsa yang multikultural harus mengembangkan wawasan multikultural tersebut dalam semua tatanan kehidupan yang bernafaskan nilai- nilaikebhinekaan. Membangun masyarakat multikultur Indonesia harus diawali dengan keyakinan bahwa dengan bersatu kita memiliki kekuatan yang lebih besar.
\end{abstract}

Kata Kunci: Manusia, Kebudayaan

\section{PENDAHULUAN}

Indonesia adalah negara yang memiliki kekayaan yang tersebar mulai dari Sabang sampai Merauke, dengan beragam suku dan ras sehingga menghasilkan kebudayaan yang beraneka ragam. Kekayaan yang dimiliki oleh masyarakat Indonesia tersebut bukan hanya berupa kekayaan sumber alam saja, tetapi masyarakat Indonesia juga memiliki kekayaan lain seperti kekayaan akan kebudayaan suku bangsa Indonesia yang tersebar di seluruh kepulauan Indonesia.

Manusia dan kebudayaan merupakan salah satu ikatan yang tak bisa dipisahkan dalam kehidupan ini. Manusia sebagai makhluk Tuhan yang paling sempurna menciptakan kebudayaan mereka sendiri dan melestarikannya secara turun menurun. Budaya tercipta dari kegiatan sehari hari dan juga dari kejadian - kejadian yang sudah diatur oleh Yang Maha Kuasa. Selain itu manusia merupakan makhluk sosial yang berinteraksi satu sama lain dan melakukan suatu kebiasaan-kebiasaan tertentu yang pada akhirnya menjadi budaya yang biasa mereka lakukan. Kebudayaan adalah produk manusia, namun manusia itu sendiri adalah produk kebudayaan. Dengan kata lain, 
kebudayaan ada karena manusia yang menciptakannya dan manusia dapat hidup ditengah kebudayaan yang diciptakannya. Kebudayaan akan terus hidup manakala ada manusia sebagai pendudukungnya dan kebudayaan mempunyai kegunaan yang sangat besar bagi manusia di dalam kehidupannya.

Kebudayaan adalah suatu fenomena universal. Setiap masyarakat-bangsa di dunia memiliki kebudayaan, meskipun bentuk dan coraknya berbeda-beda dari masyarakatbangsa yang satu kemasyarakat-bangsa lainnya. Kebudayaan secara jelas menampakkan kesamaan kodrat manusia dari berbagai suku, bangsa, dan ras. ${ }^{1}$ Setiap kebudayaan pasti memiliki wadah dan masyarakat adalah wadah dari kebudayaan tersebut, sehingga antara kebudayaan dan masyarakat keduanya tidak dapat dipisahkan. ${ }^{2}$

\section{PEMBAHASAN}

\section{Pengertian Manusia}

Manusia dalam bahasa inggris disebut man. Arti dasar dari kata ini tidak jelas tetapi pada dasarnya dapat dikaitkan dengan mens (latin) yang berarti "ada yang berfikir". Demikian halnya arti kata anthropos (yunani) tidak begitu jelas.Semula anthropos berarti "seseorang yang melihat ke atas".Sekarang kata ini di pakai untuk mengartikan "wajah manusia".Dan akhirnya homo bahasa latin yang artinya "orang yang dilahirkan di atas bumi". ${ }^{3}$ Pada dasarnya,manusia adalah makhluk individu manusia yang merupakan bagian dan unit terkecil dari kehidupan sosial atau manusia sebagai makhluk sosial yang membentuk suatu kehidupan masyarakat, manusia merupakan kumpulan dari berbagai individu.

Manusia adalah makhluk yang diciptakan oleh Allah swt. yang pada hakikatnya mereka sebagai makhluk individu. Adapun yang dimaksud individu menurut Effendi, adalah berasal dari kata in dan divided. Dalam bahasa Inggris in mengandung pengertian tidak, sedangkan divided artinya terbagi. Jadi individu artinya tidak terbagi atau satu kesatuan. Dalam hal ini, artinya bahwa manusia sebagai makhluk individu merupakan kesatuan aspek jasmani dan rohani atau fisik dan psikologis, apabila kedua aspek tersebut sudah tidak menyatu lagi maka seseorang tersebut tidak dapat dikatakan sebagai individu. ${ }^{4}$

Manusia sebagai makhluk individu memiliki keunikan atau ciri khas masingmasing, tidak ada manusia yang persis sama meskipun terlahir kembar. Secara fisik mungkin manusia akan memiliki banyak persamaan namun secara psikologis akan banyak menunjukan perbedaan. Ciri khas dan perbedaan tersebut sering disebut dengan kepribadian. Kepribadian seseorang akan sangan dipengaruhi oleh faktor bawaan dan lingkungannya. Lebih lanjut, dalam pandangan humanistik, manusia memiliki potensi lebih banyak daripada apa yang mereka capai. Lebih lanjut dijelaskan bahwa apabila

\footnotetext{
${ }^{1}$ Rafael Raga Maran, Manusia Dan Kebudayaan Dalam Perspektif Ilmu Budaya Dasar (Jakarta: Rineka Cipta, 2007), hal. 15.

${ }^{2}$ Santri Sahar, Pengantar Antropologi: Integrasi Ilmu Dan Agama (Makassar: Cara Baca, 2015), hal.156.

${ }^{3}$ A.Haris Hermawan, Filsafat Pendidikan Islam (Jakarta: Direktorat Jendral Pendidikan Islam Depertemen Agama, 2009), hal. 44.

${ }^{4}$ Effendi, R. dan Setiadi, Pendidikan Lingkungan, Sosial, Budaya dan Teknologi (Bandung: UPI Press, 2010), hal. 37
} 
dapat melepaskan potensi itu, maka setiap individu dapat mencapai keadaan eksistensi yang ideal yang ditemukannya dalam orang-orang yang mengaktualisasikan diri. ${ }^{5}$

Menurut Nursid Sumaatmadja dalam Effendi, kepribadian adalah keseluruhan perilaku individu yang merupakan hasil interaksi antara potensi-potensi bio-psiko-fisikal (fisik dan psikis) yang terbawa sejak lahir dengan rangkaian situasi lingkungan, yang terungkap pada tindakan dan perbuatan serta reaksi mental psikologisnya jika mendapat rangsangan dari lingkungan.Dia menyimpulkan bahwa faktor lingkungan (fenotip) ikut berperan dalam pembentukkan karakteristik yang khas dari seseorang.Secara normal, setiap manusia memiliki potensi dasar mental yang berkembang dan dapat dikembangkan yang meliputi (1) minat (sense of interest), (2) dorongan ingin tahu (sense of curiousity), (3) dorongan ingin membuktikan kenyataan (sense of reality) (4) dorongan ingin menyelidiki (sense of inquiry), (5) dorongan ingin menemukan sendiri (sense of discovery). Potensi ini berkembang jika adanya rangsangan, wadah dan suasana kondusif. Jika fenomena sosial di lingkungannya telah tumbuh potensi-potensi mental yang normalnya akan terus berkembang. ${ }^{6}$

Berawal dari potensi-potensi tersebut, manusia sebagai makhluk individu ingin memenuhi kebutuhan dan kehendaknya masing masing, ingin merealisasikan dan mengaktualisasikan dirinya. Dalam arti ia memiliki kemampuan untuk mengembangkan potensi-potensi yang dimilikinya. Setiap individu akan berusaha semaksimal mungkin untuk menemukan jati dirinya yang berbeda dengan yang lainnya, tidak ada manusia yang betul-betul ingin menjadi orang lain, dia tetap ingin menjadi dirinya sendiri sehingga dia selalu sadar akan keindividualitasnya. Menurut Zanti Arbi dan Syahrun dalam Sadulloh, menyatakan bahwa setiap orang bertanggung jawab atas dirinya, atas pikiran, perasaan, pilihan, dan perilakunya. Orang yang betul-betul manusia adalah orang yang bertanggung jawab penuh. Tidak ada orang lain yang mengambil alih tanggung jawab dalam hidupnya. Kata hatinya adalah kata hatinya sendiri. ${ }^{7}$

Adapun dalam hal ini sebagai pendidik baik orang tua maupun guru kita harus memahami bahwa anak memiliki potensi untuk berkembang yang ingin menjadi pribadinya sendiri. Anak dalam perkembangannya akan memperoleh pengeruh dari luar, baik yang disengaja ataupun yang tidak disengaja, tetapi anak akan mengambil jarak terhadap pengaruh-pengaruh tersebut. Dia akan memilihnya sendiri. Pengaruh tersebut akan dia olah secara pribadi, sehingga apa yang dia terima akan merupakan bagian dari dirinya sendiri sehingga anak menjadi pribadi individu yang berbeda dan tidak sama dengan yang lainnya. Selain itu, pendidik harus sadar bahwa anak bukan satu satunya manusia yang berhak untuk mendidik anak tersebut. pendidikan tidak boleh memaksa anak untuk mengikuti atau menuruti segala kehendaknya, karena dalam diri anak ada suatu prinsip pembentukan dan pengembangan yang ditentukan oleh dirinya sendiri.

\footnotetext{
${ }^{5}$ Sidik, Firman. "Pendidikan Humanis dan Implikasinya Dalam Pembelajaran." Tadbir: Jurnal Manajemen Pendidikan Islam 4.1 (2016): 88-95.

${ }^{6}$ Ibid., hal. 39

${ }^{7}$ Sadulloh, Pengantar Filsafal Pendidikan (Bandung: Alfabeta, 2003), hal. 81
} 
Menurut kodratnya manusia selain sebagai makhluk individu, mereka juga merupakan makhluk sosial. Manusia dapat di katakan makluk sosial karena pada dirinya terdapat dorongan untuk berhubungan atau berinteraksi dengan orang lain, dimana terdapat kebutuhan untuk mencari berteman dengan orang lain yang sering di dasari atas kesamaan ciri atau kepentingan masing-masing. Manusia juga tidak akan bisa hidup sebagai manusia kalau tidak hidup di tengah-tengah manusia. Tanpa bantuan manusia lainnya, manusia tidak mungkin bisa berjalan dengan tegak. Dengan bantuan orang lain, manusia bisa menggunakan tangan, bisa berkomunikasi atau bicara, dan bisa mengembangkan seluruh potensi kemanusiaannya. Makhluk sosial adalah makluk yang terdapat dalam beragam aktivitas dan lingkungan sosial.

\section{Pengertian Kebudayaan}

Secara etimologi kata Kebudayaan dari akar budaya yang berasal dari bahasa sangsekerta. Dari akar kata Buddhi-tunggal-, jamaknya adalah buddhayah yang diartikan budi, atau akal, atau akal budi atau pikiran. Setelah mendapat awalan ke- dan akhiran -an menjadi kebudayaan Yang berarti hal ihwal tentang alam pikiran manusia. ${ }^{8}$ Adapun istilah culture yang merupakan istilah bahasa asing yang sama artinya dengan kebududayaan berasal dari kata Latin colore. Artinya mengolah atau mengajarkan, yaitu mengolah tanah atau bertani. Dari asal arti tersebut, yaitu colore dan culture, diartikan sebagai segala daya dan kegiatan manusia untuk mengolah dan mengubah alam. ${ }^{9}$

Menurut Sir Edward B. Tylor menggunakan kata kebudayaan untuk menunjuk "keseluruhan kompleks dari ide dan segala sesuatu yang dihasilkan manusia dalam pengalaman historinya". Termasuk disini ialah "pengetahuan, kepercayaan, seni, moral, hokum, kebiasaan, dan kemampuan serta perilaku lainnya yang diperoleh manusia sebagai anggota masyarakat. Menurut Robert H. Lowie, kebudayaan adalah "segala sesuatu yang diperoleh oleh individu dari masyarakat, mencakup kepercayaan, adatistiadat, norma-norma artistic, kebiasaan makan, keahlian yang diperoleh bukan karena kreativitasnya sendiri melainkan merupakan warisan masa lampau yang dapat melalui pendidikan formal atau imformal". Menurut Clyde Kluckhohn, mendefisikan kebudayaan sebagai "total dari cara hidup suatu bangsa, warisan sosial yang diperoleh individu dari grupnya". Gillin, beranggapan bahwa "kebudayaan terdiri dari kebiasaan-kebiasaan yang terpola dan secara fungsional salingb bertautan dengan individu tertentu yang membentuk grup-grup atau kategori sosial tertentu. sedangkan menurut Koentjaraningrat, kebudayaan adalah "keseluruhan system gagasan, tindakan, dan hasil karya manusia dalam rangka kehidupan masyarakat yang dijadikan milik diri manusia dengan belajar. ${ }^{10}$

Kebudayaan tidak diwariskan secara biologis, melainkan hanya mungkin diperoleh dengan cara belajar dan kebudayaan tersebut diperoleh manusia sebagai anggota masyarakat. Hampir semua tindakan manusia adalah kebudayaan. Luasnya bidang kebudayaan menimbulkan adanya telahan mengenai apa sebenarnya isi dari kebudayaan itu. Pandangan para ahli tentang kebudayaan berbeda-beda, namun sama-

${ }^{8}$ Santri Sahar, Pengantar Antropologi: Integrasi Ilmu Dan Agama (Makassar: Cara Baca, 2015), hal. 98

${ }^{9}$ Soerjono Soekanto, Sosiologi Suatu Pengantar (Jakarta: Rajawali Pers, 2012), hal. 150.

${ }^{10}$ Rafael Raga Maran, Manusia Dan Kebudayaan Dalam Perspektif Ilmu Budaya Dasar (Jakarta: Rineka Cipta, 2007), hal. 26. 
sama memahami bahwa kebudayaan adalah suatu keseluruhan yang terintegrasi. Unsurunsur kebudayaan terdapat pada setiap kebudayaan dari semua manusia dimanapun berada. Selanjutnya Koentjaraningrat menyusun tujuh unsur-unsur kebudayaan yang bersifat universal berdasarkan pendapat para ahli antropologi.

Tujuh unsur kebudayaan yang dimaksud adalah :

a. Bahasa.

b. Sistem pengetahuan.

c. Organisasi sosial.

d. Sistem peralatan hidup dan teknologi.

e. Sistem mata pencarian hidup.

f. Sistem religi.

g. Sistem kesenian. ${ }^{11}$

Koenjtaraningrat dalam Warsito, wujud kebudayaan dibedakan menjadi tiga bagian yaitu:

1) Wujud kebudayaan sebagai suatu kompleks dari ide-ide, gagasan, nilai-nilai, normanorma, peraturan, dan sebagainya.

2) Wujud kebudayaan sebagai suatu kompleks aktivitas serta tindakan berpola dari manusia dalam masyarakat.

3) Wujud kebudayaan berupa benda-benda hasil karya manusia. ${ }^{12}$

Ketiga wujud yang telah disebutkan di atas, dalam kenyataan kehidupan msyarakat tidak dapat dipisahkan satu sama lain. Kebudayaan ideal dan adat istiadat mengatur dan memberi arah kepada tindakan dan karya manusia.Pikiran dan ide-ide maupun tindakan dan karya manusia. Menghasilkan benda-benda kebudayaan fisik. Sebaliknya kebudayaan fisik membentuk suatu lingkungan hidup tertentu yang semakin lama semakin menjauhkan manusia dari lingkungan alamiahnya sehingga mempengaruhin pola-pola perbuatannya, bahkan juga cara berpikirnya.

\section{MANUSIA DALAM KEANEKARAGAMAN BUDAYA DAN PERADABAN}

Negara Indonesia adalah salah satu negara multikultur terbesar di dunia, hal ini dapat terlihat dari kondisi sosiokultural maupun geografis Indonesia yang begitu kompleks, beragam, dan luas. "Indonesia terdiri atas sejumlah besar kelompok etnis, budaya, agama, dan lain-lain yang masing- masing plural (jamak) dan sekaligus juga heterogen "aneka ragam". ${ }^{13}$ Sebagai negara yang plural dan heterogen, Indonesia memiliki potensi kekayaan multi etnis, multi kultur, dan multi agama yang kesemuanya merupakan potensi untuk membangun negara multikultur yang besar "multikultural nation-state". Keragaman masyarakat multikultural sebagai kekayaan bangsa di sisi lain sangat rawan memicu konflik dan perpecahan. Sebagaimana yang dikemukakan oleh Nasikun bahwa kemajemukan masyarakat Indonesia paling tidak dapat dilihat dari dua cirinya yang unik, pertama secara horizontal, ia ditandai oleh kenyataan adanya kesatuan-kesatuan sosial berdasarkan perbedaan suku bangsa, agama, adat, serta perbedaan kedaerahan, dan

\footnotetext{
${ }^{11}$ Wahyuni, Perilaku Beragama Studi Sosiologi Terhadap Asimilasi Agama dan Budaya Di Sulawesi Selatan (Makassar: Alauddin University Press, 2013), hal. 39-41.

${ }^{12}$ Warsito, Antropogi Budaya (Yogyakarta: Ombak, 2012), hal. 53-55.

${ }^{13}$ Kusumohamidjojo, Kebhinnekaan Masyarakat Indonesia: Suatu Proble- matik Filsafat Kebudayaan (Jakarta: Grasindo, 2000), hal. 45
} 
kedua secara vertikal ditandai oleh adanya perbedaan-perbedaan vertikal antara lapisan atas dan lapisan bawah yang cukup tajam. ${ }^{14}$

Pluralitas dan heterogenitas yang tercermin pada masyarakat Indonesia diikat dalam prinsip persatuan dan kesatuan bangsa yang kita kenal dengan semboyan "Bhinneka Tunggal Ika", yang mengandung makna meskipun Indonesia berbhinneka, tetapi terintegrasi dalam kesatuan. Hal ini merupakan sebuah keunikan tersendiri bagi bangsa Indonesia yang bersatu dalam suatu kekuatan dan kerukunan beragama, berbangsa dan bernegara yang harus diinsafi secara sadar. Namun, kemajemukan terkadang membawa berbagai persoalan dan potensi konflik yang berujung pada perpecahan. Hal ini menggam- barkan bahwa pada dasarnya, tidak mudah mempersatukan suatu keragaman tanpa didukung oleh kesadaran masyarakat multikultural.Terlebih, kondisi masyarakat Indonesia adalah masyarakat yang paling majemuk di dunia, selain Amerika Serikat dan India. Sejalan dengan hal tersebut, Geertz dalam Hardiman, mengemukakan bahwa Indonesia ini sedemikian kompleksnya, sehingga sulit melukiskan anatominya secara persis. Negeri ini bukan hanya multietnis (Jawa, Batak, Bugis, Aceh, Flores, Bali, dan seterusnya), melainkan juga menjadi arena pengaruh multimental (India, Cina, Belanda, Portugis, Hindhuisme, Buddhisme, Konfusianisme, Islam, Kristen, Kapitalis, dan seterusnya). ${ }^{15}$

Negara yang memiliki keunikan multientis dan multimental seperti Indonesia dihadapkan pada dilematisme tersendiri, di satu sisi membawa In- donesia menjadi bangsa yang besar sebagai multicultural nation-state, tetapi di sisi lain merupakan suatu ancaman. Maka bukan hal yang berlebihan bila ada ungkapan bahwa kondisi multikultural diibaratkanseperti bara dalam sekam yang mudah tersulut dan memanas sewaktu- waktu. Kondisi ini merupakan suatu kewajaran sejauh perbedaan disadari dan dihayati keberadaannya sebagai sesuatu yang harus disikapi dengan toleransi. Namun, ketika perbedaan tersebut mengemuka dan menjadi sebuah ancaman untuk kerukunan hidup, hal ini dapat menjadi masalah yang harus diselesaikan dengan sikap yang penuh toleransi. Menyoal tentang rawan terjadi konflik pada masyarakat multikultur seperti Indonesia, memiliki potensi yang besar terjadinya konflik antarkelompok, etnis, agama, dan suku bangsa. Salah satu indikasinya yaitu mulai tumbuh suburnya berbagai organisasi kemasyarakatan, profesi, agama, dan organisasi atau golongan yang berjuang dan bertindak atas nama kepentingan kelompok yang mengarah pada konflik SARA (suku, agama, ras dan antar golongan).

Indonesia adalah suatu negara multikultural yang memiliki keragaman budaya, ras, suku, agama dan golongan yang kesemuanya merupakan kekayaan tak ternilai yang dimiliki bangsa Indo- nesia. Selo Soemardjan mengemukakan bahwa pada waktu disiapkannya Republik Indonesia yang didasarkan atas Pancasila tampaknya para pemimpin kita menyadari realitas bahwa ditanah air kita ada aneka ragam kebudayaan yang masing-masing terwadahkan di dalam suatu suku. Realitas ini tidak dapat diabaikan

\footnotetext{
${ }^{14}$ Nasikun, Sistem Sosial Indonesia (Jakarta: PT. RajaGrafindo Persada, 2007), hal. 33

${ }^{15}$ Hardiman, F. B, Belajar dari Politik Multikulturalisme. Pengantar dalam Kimlicka Kewargaan Multikul- tur: Teori Liberal Mengenal Hak-Hak Minoritas. Terjemahan oleh Edlina Efmini Eddin dari Jurnal Multicultural Citizenship: A Liberal Theory of Minority. Jakarta: LP3ES, 2002), hal. 4
} 
dan secara rasional harus diakui adanya. Founding Father bangsa menyadari bahwa keragaman yang dimiliki bangsa merupakan realitas yang harus dijaga eksistensinya dalam persatuan dan kesatuan bangsa. Keragaman merupakan suatu kewajaran sejauh disadari dan dihayati keberadaannya sebagai sesuatu yang harus disikapi dengan toleransi. Kemajemukan ini tumbuh dan berkembang ratusan tahun lamanya sebagai warisan dari nenek moyang bangsa Indonesia. Hefner dalam Mahfud, memaparkan bahwa:Pluralisme kultural di Asia Tenggara, khususnya Indonesia, Malaysia, dan Singapura sangatlah mencolok, terdapat hanya beberapa wilayah lain di dunia yang memiliki pluralisme kultural seperti itu. Karena itulah dalam teori politik Barat dasawarsa 1930-an dan 1940-an, wilayah ini, khususnya Indonesia dipandang sebagai "lokus klasik" bagi konsep masyarakat majemuk/ plural (plural society) yang diperkenalkan ke dunia Barat oleh JS Furnivall. ${ }^{16}$

Pandangan Hefner yang mengatakan bahwa Indonesia merupakan "lokus klasik" (tempat terbaik/ rujukan) bagi konsep masyarakat majemuk bukan sesuatu yang berlebihan. Hal ini terlihat dari keberagaman yang dimiliki Indonesia sebagai bangsa yang unik dimana hanya beberapa wilayah saja di dunia yang dianugrahi keistime- waan ini. Telaah mengenai keberagaman sebuah bangsa kemudian dikenal dengan konsep multikultural. Banyak ahli mengemukakan bahwa konsep multikultural pada dasarnya merupakan konsepharmoni dalam keragaman budaya yang tumbuh seiring dengan kesederajatan diatara budaya yang berbeda.Harmoni ini menuntut setiap individu untuk memiliki penghargaan terhadap kebudayaan individu lain yang hidup dalam komunitasnya. Dalam masyarakat multikultur, setiap individu maupun masyarakat memiliki kebutuhan untuk diakui (politics of recognition) yang menuntut terciptanya penghargaan tertentu secara sosial. Multikultural dapat diartikan sebagai keragaman atau perbedaan terhadap suatu kebudayaan dengan kebudayaan yang lain. Menurut Bhiku Parekh dalam Azra mengatakan bahwa Masyarakat multikultural adalah suatu masyarakat yang terdiri dari beberapa macam komunitas budaya dengan segala kelebihannya, dengan sedikit perbedaan konsepsi mengenai dunia, suatu sistem arti, nilai, bentuk organisasi sosial, sejarah, adat serta kebiasaan. ${ }^{17}$

Sejalan dengan pandangan tersebut, Musa Asy'arie (dalam Mahfud ${ }^{18}$, mengatakan bahwa "multikulturalisme adalah kearifan untuk melihat keanekaragaman budaya sebagai realitas fundamental dalam kehidupan bermasyarakat". Kearifan akan tumbuh jika seseorang membuka diri untuk menjalani kehidupan bersama dengan melihat realitas plural sebagai kepastian hidup yang kodrati.Kearifan dapat tumbuh baik dalam kehidupan diri sebagai individu yang multidimen- sional maupun dalam kehidupan masyarakat yang lebih kompleks. Dengan demikian, muncul suatu kesadaran bahwa keanekaragaman dalam realitas dinamika kehidupan adalah suatu keniscayaan yang tidak bisa ditolak, diingkari, apalagi dimusnahkan. "Multikulturalisme adalah landasan budaya yang terkait dengan pencapaian civility (keadaban), yang amat esensial bagi terwujudnya demokrasi yang

${ }^{16}$ Mahfud, C, Pendidikan Multikultural (Yogyakarta: Pustaka Pelajar, 2005), hal. 83

${ }^{17}$ Azra, A. "Pancasila dan Identitas Nasional Indonesia: Perspektif Multikulturalisme". Dalam Restorasi Pancasila: Mendamaikan Politik Identitas dan Modernitas, (Bogor: Brighten Press. Jakarta: Rineka Cipta, 2006), hal. 62

${ }^{18}$ Mahfud, C, Pendidikan Multikultural ..., hal. 103 
berkeadaban, dan keadaban yang demokratis. ${ }^{19}$ Kedalam atau civility yang dikemukakan oleh Azra sejalan dengan pendapat yang dikemukakan oleh Ki Hajar Dewantara yang menyatakan bahwa "kebudayaan Indonesia merupakan puncak-puncak budaya dari masingmasing suku bangsa. Puncak-puncak kebudayaan dari suatu suku bangsa merupakan unsur-unsur budaya lokal yang dapat memperkuat solidaritas nasional". Solidaritas nasional terbentuk dari keadaban yang tumbuh dan berkembang dalam kehidupan masyarakat. ${ }^{20}$

Dengan pencapaian civility (keadaban) di masyarakat, maka akan terbentuk suatu kekuatan solidaritas nasional. Pengembangan wawasan multikultural sebagaimana telah dipaparkan di atas mutlak harus dibentuk dan ditanamkan dalam suatu kehidupan masyarakat yang majemuk. Jika hal tersebut tidak ditanamkan dalam suatu masyarakat yang majemuk, maka kemajemukan akan membawa pada perpecahan dan konflik. Indone- sia sebagai bangsa yang multikultural harus mengembangkan wawasan multikultural tersebut dalam semua tatanan kehidupan yang harmonis.

Kemungkinan munculnya benih-benih percekcokan pada masyarakat multikultur sangat rawan terjadi jika masyarakat multikultur menyikapi perbedaan sebagai suatu pemisah dan menimbulkan sifat ke-kita-an (yang lain bukan bagian dari kita). Masyarakat yang hidup ribuan tahun dalam keadaan yang multikultur tidak berarti telah immune terhadap kemungkinan-kemung- kinan gesekan konflik etnis, budaya, agama, sosial, politik dan ekonomi. Pengalaman lama hidup dalam perbedaan ternyata tidak cukup untuk menanamkan rasa bangga akan perbedaan dan memandangnya sebagai suatu kekayaan bangsa. Menyikapi hal tersebut, Azyumardi Azra memandang bahwa pembentukan masyarakat multikultural Indonesia yang sehat tidak bisa secara taken for granted atau trial and error. Harus diupayakan secara sistematis, programatis, integrated dan berkesinambungan. Salah satu strategi penting itu adalah pendidikan multikultural yang dapat berlangsung dalam setting pendidikan formal atau informal, langsung atau tidak langsung. ${ }^{21}$

\section{MANUSIA DENGAN LINGKUNGAN DAN SUMBER PENGHIDUPAN}

Lingkungan adalah keadaan sekitar yang mempengaruhi perkembangan dan tingkah laku makhluk hidup. ${ }^{22}$ Segala sesuatu yang ada di sekitar manusia yang mempengaruhi perkembangan kehidupan manusia baik langsung maupun tidak langsung juga merupakan pengertian lingkungan. Lingkungan hidup dapat didefinisikan sebagai: 1) daerah tempat suatu makhluk hidup berada; 2) keadaan atau kondisi yang melingkupi suatu makhluk hidup; 3) keseluruhan keadaan yang meliputi suatu makhluk hidup atau sekumpulan makhluk hidup. ${ }^{15}$ Menurut Undang Undang RI No. 4 tahun 1982, tentang Kententuan-ketentuan Pokok Pengelolaan Lingkungan Hidup dan Undang-Undang RI No. 32 Tahun 2009, tentang Pengelolaan Lingkungan Hidup, dikatakan bahwa: Lingkungan hidup adalah kesatuan ruang dengan semua benda, daya, keadaan, dan

\section{${ }^{19}$ Azra, A, Konflik Baru Antar Peradaban: Globalisasi, Radikalisme dan} Pluralitas. Jakarta: PT. Raja Grafindo Persada, 2002), hal. 53

${ }^{20}$ Tilaar, H. A. R, Mengindonesiakan Etnisitas dan Identitas Bangsa Indone- sia. Jakarta: Rineka Cipta, 2007), hal. 33

${ }^{21}$ Azra, Op Cit., hal. 31

${ }^{22}$ Anonim, Kamus Besar Bahasa Indonesia (Jakarta: Balai Pustaka, 2005), hal. 877. 
makhluk hidup, termasuk manusia dan perilakunya, yang mempengaruhi alam itu sendiri, kelangsungan perikehidupan, dan kesejahteraan manusia serta makhluk hidup lain.

Otto Soemarno, seorang pakar lingkungan mendefinisikan lingkungan hidup sebagai berikut: lingkungan adalah jumlah semua benda dan kondisi yang ada dalam ruang yang kita tempati yang mempengaruhi kehidupan kita. ${ }^{23}$ Pengertian lingkungan hidup menurut S. J. McNaughton dan Larry L. Wolf adalah semua faktor eksternal yang bersifat biologis dan fisika yang langsung mempengaruhi kehidupan, pertumbuhan, perkembangan, dan reproduksi manusia. Menurut Emil Salim (1985) dalam bukunya: Lingkungan Hidup dan Pembangunan, menyatakan bahwa lingkungan hidup adalah segala benda, daya, kondisi, keadaan dan pengaruh yang terdapat dalam ruang yang kita tempati dan mempunyai hal-hal yang hidup termasuk kehidupan manusia. ${ }^{2417}$ Lingkungan hidup menurut Mohamad Soerjani dan Surna T. Djajadiningrat (1985) dikaji oleh ilmu lingkungan yang landasan pokoknya adalah ekologi, serta dengan mempertimbangkan disiplin lain, terutama ekonomi dan geografi. ${ }^{25}$ Berdasarkan pendapat tokoh-tokoh di atas, maka harus adanya pemahaman yang seimbang tentang prinsip dan konsep dasar, serta saling keterkaitan antara ekologi, ekonomi dan geografi untuk mewujudkan lingkungan hidup yang selaras.

Sifat lingkungan hidup ditentukan oleh beberapa faktor. Pertama, jenis dan masing-masing jenis unsur lingkungan hidup tersebut. Kedua, hubungan atau interaksi antar unsur dalam lingkungan hidup itu. Ketiga, kelakuan atau kondisi unsur lingkungan hidup. Keempat, faktor non-materiil suhu, cahaya dan kebisingan. ${ }^{26}$ Faktor-faktor inilah yang menentukan lingkungan hidup akan menjadi lebih baik atau akan menjadi lebih buruk. Untuk menciptakan lingkungan yang harmonis, antara faktor lingkungan dan lingkungannya haruslah seimbang. Dengan peka atau sadar terhadap lingkungan, maka lingkungan akan menjadi lebih baik serta dapat memberikan sesuatu yang positif yang dapat kita manfaatkan dengan baik.

Dari berbagai pengertian lingkungan yang sama itu perlu disadari bahwa pengelolaan oleh manusia sampai saat ini tidak sesuai dengan etika lingkungan. Etika lingkungan sangat dibutuhkan untuk menyeimbangkan alam semesta, sementara itu manusia beranggapan bahwa manusia bukan bagian dari alam semesta sehingga manusia secara bebas mengelolanya bahkan sampai merusak lingkungan hidup. Dalam Kamus Umum Bahasa Indonesia, etika diartikan ilmu pengetahuan tentang asas-asas akhlak (moral). Etika adalah sebuah cabang filsafat yang berbicara mengenai nilai dan norma dalam menentukan perilaku manusia. ${ }^{27}$ Etika lingkungan merupakan kebijakan moral manusia dalam berhubungan dengan lingkungannya. Etika lingkungan sangat diperlukan agar setiap kegiatan yang menyangkut lingkungan dipertimbangkan secara cermat sehingga keseimbangan lingkungan tetap terjaga.

\footnotetext{
${ }^{23}$ Bahrudin Supardi, Berbakti Untuk Bumi,(Bandung: Rosdakarya, 2009), hal. 11.

${ }^{24}$ Amos Neolaka, Kesadaran Lingkungan (Jakarta: PT. Rineka Cipta, 2008), hal. 27.

${ }^{25}$ Ibid., hal. 30

${ }^{26}$ Otto Soemarwono, Ekologi Lingkungan Hidup dan Pembangunan (Bandung: Djambatan, 1994), hal. 53-54.

${ }^{27}$ Nadjmuddin Ramly, Membangun Lingkungan Hidup yang Harmonis \& Berperadaban (Jakarta: Grafindo Khazanah Ilmu, 2005), hal. 22.
} 
Di dalam etika lingkungan terdapat prinsip-prinsip yang digunakan. Adapun prinsip-prisip etika lingkungan menurut Sony Keraf antara lain:

1. Sikap hormat terhadap alam

2. Prinsip tanggung jawab

3. Solidaritas kosmis

4. Kasih sayang dan kepedulian terhadap alam

5. Tidak merugikan

6. Hidup sederhana dan serasi dengan alam

7. Keadilan

8. Demokrasi

9. Integritas moral. ${ }^{28}$

Kepedulian terhadap lingkungan hidup dapat ditinjau dengan dua tujuan utama: pertama, dalam hal tersedianya sumber daya alam, sampai sejauhmana sumber-sumber tersebut secara ekonomik menguntungkan untuk digali dan kemudian dimanfaatkan sebagai sumber pendapatan guna membiayai kegiatan pembagunan. Kedua, jika kekayaan yang dimiliki memang terbatas dan secara ekonomik tidak menguntungkan untuk digali dan diolah, maka untuk selanjutnya strategi apa yang perlu ditempuh untuk memenuhi kebutuhan dan tuntutan pembagunan bangsa yang bersangkutan. ${ }^{29}$ Pengelolaan lingkungan dapat kita artikan sebagai usaha sadar untuk memelihara atau memperbaiki mutu lingkungan agar kebutuhan dasar kita dapat terpenuhi dengan sebaik-baiknya. ${ }^{30}$ Sadar lingkungan adalah kesadaran untuk mengarahkan sikap dan pengertian masyarakat terhadap pentingnya lingkungan yang bersih, sehat dan sebagainya. Faktor-faktor yang mempengaruhi kesadaran lingkungan: ${ }^{26}$

1) Faktor ketidaktahuan

Tidak-tahu berlawanan dengan kata tahu. Poedjawijatna menyatakan bahwa sadar dan tahu itu sama $($ sadar $=$ tahu). Jadi apabila berbicara tentang ketidaktahuan maka hal itu juga membicarakan ketidaksadaran. Seseorang yang tahu akan arti pentingnya lingkungan sehat bagi makhluk hidup, maka orang tersebut akan senantiasa menjaga dan memelihara lingkungan.

2) Faktor kemiskinan

Kemiskinan membuat orang tidak peduli dengan lingkungan. kemiskinan adalah keadaan ketidakmampuan untuk memenuhi kebutuhan hidup minimum. Dalam keadaan miskin, sulit sekali berbicara tentang kesadaran lingkungan, yang dipikirkan hanya cara mengatasi kesulitannya, sehingga pemikiran tentang pengelolaan lingkungan menjadi terabaikan.

3) Faktor kemanusiaan

Kemanusiaan diartikan sebagai sifat-sifat manusia. Menurut Chiras (1991) dikatakan manusia adalah bagian dari alam atau pengatur alam. Pengatur atau penguasa

${ }^{28}$ Prabang Setyono, Etika, Moral dan Bunuh Diri Lingkungan dalam Perspektif Ekologi (Solusi Berbasis Enviromental Insight Quotient) (Surakarta: UNS Press dan LPP UNS, 2011), hal. 8-10.

\footnotetext{
${ }^{29}$ Nadjmuddin Ramly, Membangun Lingkungan Hidup..., hal. 28.

${ }^{30}$ Otto Soemarwono, Ekologi Lingkungan Hidup.., hal. 76.
} 
disini diartikan manusia memiliki sifat serakah, yaitu sifat yang menganggap semuanya untuk dirinya dan keturuannya. ${ }^{27}$ Adanya sifat dasar manusia yang ingin berkuasa maka manusia tersebut mengenyampingkan sifat peduli terhadap sesama.

4) Faktor gaya hidup

Dengan perkembangan Ilmu Pengetahuan dan Teknologi (Iptek) dan teknologi informasi serta komunikasi yang sangat pesat, tentunya berpengaruh pula terhadap gaya hidup manusia. Gaya hidup yang mempengaruhi perilaku manusia untuk merusak lingkungan adalah gaya hidup hedonisme (berfoya-foya), materialistik (mengutamakan materi), sekularisme (mengutamakan dunia), konsumerisme (hidup konsumtif), serta individualisme (mementingkan diri sendiri). ${ }^{31}$

Pandangan yang beranggapan alam bernilai hanya sejauh ia bermanfaat bagi kepentingan manusia akan menimbulkan kepedulian lingkungan yang dangkal serta perhatian kepada kepentingan ligkungan sering diabaikan. ${ }^{32}$ Namun sangat disanyangkan, keadaan alam sekarang dibandingkan 10-20 tahun yang lalu sangat terasa adanya perbedaan yang mencolok, hal ini tidak lain karena terjadinya eksploitasi besar-besaran oleh manusia baik secara sadar maupun tak sadar. Lingkungan hidup baik biotik maupun abiotik berpengaruh dan dipengaruhi oleh manusia.

\section{KESIMPULAN}

Secara sederhana hubungan manusia dan kebudayaan adalah sebagai perilaku kebudayaan dan kebudayaan merupakan obyek yang dilaksanakan manusia. Dalam ilmu sosiologi manusia dan kebudayaan dinilai sebagai dwi tunggal yang berarti walaupun keduanya berbeda tetapi keduanya merupakan satu kesatuan. Manusia menciptakan kebudayaan setelah kebudayaan tercipta maka kebudayaan mengatur kehidupan manusia yang sesuai dengannyaLingkungan hidup pada dasarnya adalah suatu system kehidupan dimana terdapat campur tangan manusia terhadap tatanan ekosistem. Manusia adalah bagian dari ekosistem. Lingkungan dapat pula berbentuk lingkungan fisik dan non fisik. Lingkungan alam dan buatan adalah Lingkungan fisik. Sedangkan lingkungan nonfisik adalah lingkungan social budaya dimana manusia itu berada. Lingkungan amat penting bagi kehidupan manusia. Segala yang ada pada lingkungan dapat dimanfaatkan oleh manusia untuk mencukupi kebutuhan hidup manusia, karma lingkungan memiliki daya dukung, yaitu kemampuan lingkungan untuk mendukung perkehidupan manusia dan makhuk hidup lainya arti penting lingkungan bagi manusia karena lingungan merupakan tempat hidup manusia, Lingkungan memberi sumber-sumber penghidupan manusia, Lingkungan memengaruhi sifat, karakter, dan perilaku manusia yang mendiaminya.

\section{DAFTAR PUSTAKA}

Anonim, Kamus Besar Bahasa Indonesia, Jakarta: Balai Pustaka, 2005.

Azra, A, Konflik Baru Antar Peradaban: Globalisasi, Radikalisme dan Pluralitas. Jakarta: PT. Raja Grafindo Persada, 2002.

Azra, A. "Pancasila dan Identitas Nasional Indonesia: Perspektif Multikulturalisme". Dalam Restorasi Pancasila: Mendamaikan Politik Identitas dan Modernitas, (Bogor: Brighten Press, Jakarta: Rineka Cipta, 2006.

\footnotetext{
${ }^{31}$ Amos Neolaka, Kesadaran Lingkungan.., hal. 41.

${ }^{32}$ Prabang Setyono, Etika, Moral dan Bunuh Diri Lingkungan..., hal. 36.
} 
C, Mahfud. Pendidikan Multikultural, Yogyakarta: Pustaka Pelajar, 2005.

Effendi, R. dan Setiadi, Pendidikan Lingkungan, Sosial, Budaya dan Teknologi, Bandung: UPI Press, 2010.

Hardiman, F. B, Belajar dari Politik Multikulturalisme. Pengantar dalam Kimlicka Kewargaan Multikul- tur: Teori Liberal Mengenal Hal-Hak Minoritas. Terjemahan oleh Edlina Efmini Eddin dari Jurnal Multicultural Citizenship: A Liberal Theory of Minority. Jakarta: LP3ES, 2002.

Haris, A. Hermawan, Filsafat Pendidikan Islam, Jakarta: Direktorat Jendral Pendidikan Islam Depertemen Agama, 2009.

Kusumohamidjojo, Kebhinnekaan Masyarakat Indonesia: Suatu Proble- matik Filsafat Kebudayaan Jakarta: Grasindo, 2000.

Maran, Rafael Raga. Manusia Dan Kebudayaan Dalam Perspektif Ilmu Budaya Dasar, Jakarta: Rineka Cipta, 2007.

Neolaka, Amos. Kesadaran Lingkungan, Jakarta: PT. Rineka Cipta, 2008.

Nasikun, Sistem Sosial Indonesia, Jakarta: PT. RajaGrafindo Persada, 2007.

Ramly, Nadjmuddin. Membangun Lingkungan Hidup yang Harmonis \& Berperadaban, Jakarta: Grafindo Khazanah Ilmu, 2005.

Sadulloh, Pengantar Filsafal Pendidikan, Bandung: Alfabeta, 2003.

Sahar, Santri. Pengantar Antropologi: Integrasi Ilmu Dan Agama, Makassar: Cara Baca, 2015.

Setyono, Prabang. Etika, Moral dan Bunuh Diri Lingkungan dalam Perspektif Ekologi (Solusi Berbasis Enviromental Insight Quotient), Surakarta: UNS Press dan LPP UNS, 2011.

Sidik, Firman. "Pendidikan Humanis dan Implikasinya Dalam Pembelajaran." Tadbir: Jurnal Manajemen Pendidikan Islam 4.1 (2016): 88-95.

Soemarwono, Otto. Ekologi Lingkungan Hidup dan Pembangunan, Bandung: Djambatan, 1994.

Soekanto, Soerjono. Sosiologi Suatu Pengantar, Jakarta: Rajawali Pers, 2012.

Supardi, Bahrudin. Berbakti Untuk Bumi,Bandung: Rosdakarya, 2009

Tilaar, H. A. R, Mengindonesiakan Etnisitas dan Identitas Bangsa Indone- sia, Jakarta: Rineka Cipta, 2007.

Wahyuni, Perilaku Beragama Studi Sosiologi Terhadap Asimilasi Agama dan Budaya Di Sulawesi Selatan, Makassar: Alauddin University Press, 2013.

Warsito, Antropogi Budaya, Yogyakarta: Ombak, 2012. 